\title{
STUDI PENGARUH WAKTU, SUHU DAN JUMLAH DEHIDRATOR PADA DEHIDRASI RISINOLEAT MINYAK JARAK DENGAN $\mathrm{P}_{2} \mathrm{O}_{5}$
}

\author{
M. Sitorus 1 , S. Ibrahim ${ }^{2}$, H. Nurdin ${ }^{2}$, D. Darwis ${ }^{2}$ \\ ${ }^{1}$ Jurusan Kimia FMIPA UNIMED Medan \\ ${ }^{2} J u r u s a n$ Kimia FMIPA UNAND Padang \\ email:marham.sitorus@gmail.com
}

\begin{abstract}
The aims of study are to optimize the reaction's parameters i.e. time, temperature, and amount of dehydrator's agent on the dehydration of ricinoleic of castor oil into dehydrated castor oil (DCO) by mean $\mathrm{P}_{2} \mathrm{O}_{5}$. DCO is the mixed of linoleic acid (LA) and conjugated linoleic acid (CLA). Dehydration were carried out using various of time, temperature, and amount of dehydrator. The reaction medium was maintained under vacuum, gentle bubbling with nitrogen, magnetically stirred and used Zn's powder as antipolymerization's agent. The changes composition of DCO were analyzed by GC, and identification by FTIR and GC-MS and compared to CLA's standard. Best result were obtain for $4 \mathrm{~h}$, at $200^{\circ} \mathrm{C}$ and $3 \%(\mathrm{w} / \mathrm{w}) \mathrm{P}_{2} \mathrm{O}_{5}$. DCO compositions were : $1.02 \%$ of $(9 \mathrm{c} / \mathrm{t}-12 \mathrm{c} / \mathrm{t})$ linoleic; $41.97 \%$ of $(9 \mathrm{c} / \mathrm{t}-12 \mathrm{t} / \mathrm{c})$ linoleic $; 19.50 \%$ of $(9 \mathrm{c} / \mathrm{t}-11 \mathrm{t} / \mathrm{c}) \mathrm{CLA} ; 19.79 \%$ of $(9 t-11 t)$ CLA; and $0.90 \%$ of residual's of ricinoleic. The yields of dehydration was $98.98 \%$, and the decreased $92.98 \%$ intensities of $-\mathrm{OH}$ wives number in FTIR spectra's castor oil comparison with $\mathrm{DCO}$ to indicated transform of ricinoleic by dehydration. Both wave number of alkenes $(\mathrm{C}=\mathrm{C})$ at FTIR DCO spectra was indicated to formed of conjugated alkenes (CLA). The ratio of CLA : linoleic was $0.92: 1$ with achievement of $63.5 \%$ relatively to CLA standard with ratio of CLA : linoleic was $1.45: 1$.
\end{abstract}

Keywords: Time, Temperature, Amount of dehydrator, Dehydration of ricinoleic

\section{PENDAHULUAN}

Dehidrasi adalah salah satu jenis reaksi eliminasi yaitu pengurangan molekul air dari suatu senyawa alkohol yang menghasilkan suatu alkena. Untuk mengoptimalkan hasil maka reaksi dehidrasi dilakukan dengan menambahkan suatu reagen pereaksi yang menarik senyawa yang dieliminasi. Pada reaksi dehidrasi molekul yang dieliminasi adalah air, maka yang ditambahkan adalah reagen penarik air atau dehidrator ${ }^{[1,2]}$.

Dehidrasi alkohol telah banyak dilakukan dengan berbagai macam dehidrator antara lain dehidrasi n-alkohol dengan katalis analsim ${ }^{[3]}$, dehidrasi etanol dengan Zeolit alam yang sudah didealuminasi ${ }^{[4]}$, dehidrasi n-butanol dengan alumina aktif ${ }^{[5]}$, dehidrasi namilalkohol dengan dehidrator karbon aktif yang diinterkalasi tembaga $(\mathrm{Cu})^{[6]}$, dehidrasi isomamil alkohol dengan $\mathrm{H}_{2} \mathrm{SO}_{4}{ }^{[2]}$ dan kajian
Termodinamika dehidrasi n-butanol ${ }^{[7]}$. Dehidrator untuk risinoleat harus kemoselektif untuk mencegah reaksi samping terhadap ikatan rangkap dan triester. Beberapa dehidrasi risinoleat juga telah dilakukan dengan dehidrator yang tidak bersifat oksidator dan asam seperti molecular sieve ${ }^{[8]}$, natrium bisulfit dan bentonit dengan katalis asam sulfat ${ }^{[9-11]}$.

Dehidator difosforpentaoksida $\left(\mathrm{P}_{2} \mathrm{O}_{5}\right)$ juga merupakan dehidrator kemoselektif ${ }^{[12,13]}$. Dalam kajian ini dipelajari pengaruh tiga parameter reaksi yaitu faktor waktu $(\mathrm{t})$, suhu (T), dan jumlah relatif dehidrator $(\% \mathrm{~b} / \mathrm{b})$ pada dehidrasi risinoleat minyak jarak (castor oil). Ketiganya merupakan faktor eksternal utama yang berperan untuk keberhasilan suatu reaksi secara umum. Penggunaan dehidrator $\mathrm{P}_{2} \mathrm{O}_{5}$ pada penelitian ini didasarkan pada peneltian terdahulu yang merupakan dehidrator kemoselektif dimana belum mengkaji tiga parameter tersebut secara mendalam ${ }^{[12,13]}$. 
Dehidrasi risinoleat menghasilkan minyak jarak terdehidrasi $(\mathrm{DCO}=$ dehydrated castor oil) yaitu campuran antara linoleat $[18: 2$ (9, 12)] dan linoleat terkonjugasi (CLA = conjugated linoleic acid) $[18: 2(9,11)]$ kerena terdapat dua $\mathrm{H \alpha}$ terhadap alkohol ${ }^{[1,14]}$. Risinoleat mempunyai nama kimia 12hidroksi-9-cis enoat dengan notasi [18: 1 (9), $12(-\mathrm{OH})]$ dapat mengalami reaksi dehidrasi, dengan persamaan reaksi secara umum dalam bentuk asam lemak dapat dilihat pada Gambar 1 .

Setiap pengkajian parameter yang dipelajari dilakukan pada kondisi dua parameter lain konstan sebagai kontrol. Dehidrasi mengunakan serbuk $\mathrm{Zn}$ sebagai anti polimerisasi ikatan rangkap dengan aliran gas nitrogen untuk meminimalisasi oksigen (mencegah reaksi oksidasi), pengurangan tekanan untuk menarik air hasil dehidrasi sehingga kesetimbangan bergeser ke arah produk dan pengadukan untuk homogenisasi reaksi. Studi terhadap ketiga parameter tersebut dipandu berdasarkan analisis terhadap penurunan kadar risinoleat dan kenaikan kadar linoleat dan linoleat terkonjugasi (LA dan CLA) pada DCO dibanding dengan minyak jarak. Perobahan komposisi risinoleat dan LA dan CLA DCO selama dehidrasi dianalisis dengan GC, dan identifikasi dianalisis dengan spektrofotometer FTIR dan GC-MS ${ }^{[15,16]}$.

\section{METODOLOGI}

\section{Alat dan Bahan}

Peralatan yang digunakan adalah berbagai alat gelas, satu set alat refluks, alat GC 3890 , Spektroskopi FTIR Shimadzu dan alat GC-MS Shimadzu. Sedangkan bahan kimia habis pakai yang digunakan adalah : $\mathrm{P}_{2} \mathrm{O}_{5}$, logam natrium (Na), metanol absolut, serbuk logam $\mathrm{Zn}$ sebagai anti polimerisasi, akuades, minyak jarak terdehidrasi (DCO) dan indikator $\mathrm{pH}$ universal.<smiles>CCCCCCC=CCCC(=O)O</smiles>

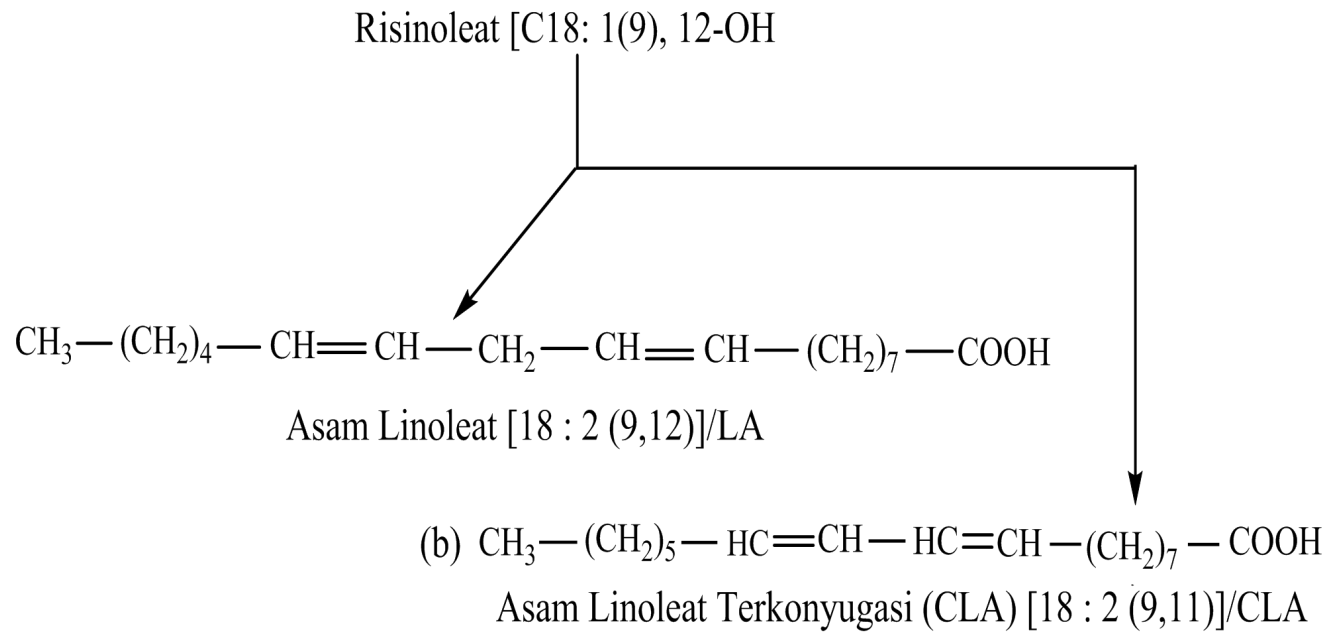

Gambar 1. Reaksi dehidrasi Risinoleat 


\section{Prosedur}

\section{Penentuan Komposisi Minyak Jarak dan DCO}

Sebanyak $15 \mathrm{~mL}$ minyak jarak atau DCO dicampur dengan $50 \mathrm{~mL}$ Na-metoksi $1 \%$ yang dibuat tersendiri dengan mereaksikan metanol dan logam Na. Selanjutnya dilakukan refluks pada suhu $60-90^{\circ} \mathrm{C}$ selama setengah jam. Hasil refluk didinginkan dan lapisan metil ester asam lemak (Fatty Acid Methyl esthers = FAME) diambil dan dinetralkan dengan akuades yang dipantau dengan indikator $\mathrm{pH}$ universal. Setelah netral dikeringkan dengan $\mathrm{Na}_{2} \mathrm{SO}_{4}$ anhidrat dan komposisinya dianalisis dengan GC dan identifikasi dengan spektrofotometer FTIR dan GC-MS.

\section{Studi Pengaruh Waktu Suhu dan Jumlah Dehidrator pada Dehidrasi}

\section{Risinoleat Minyak Jarak dengan $\mathrm{P}_{2} \mathrm{O}_{5}$}

Setiap pengkajian parameter yang dipelajari dilakukan pada kondisi dua parameter lain konstan. Reaksi dilakukan pada aliran gas Nitrogen, pengurangan tekanan $50-70 \mathrm{mmHg}$ dan kecepatan pengadukan $800-1000$ rpm dan penambahan $0,1 \mathrm{~g}$ serbuk $\mathrm{Zn}$ sebagai anti polimerisasi sebagai berikut: (1) Studi pengaruh waktu dilakukan dengan variasi waktu reaksi 1, 2, 3, 4 jam dengan jumlah dehidrator $\mathrm{P}_{2} \mathrm{O}_{5} \%(\mathrm{~b} / \mathrm{b})$ pada suhu $175^{\circ} \mathrm{C}$. (2) Studi pengaruh suhu dilakukan dengan variasi suhu $100,125,150,175,200,225^{\circ} \mathrm{C}$ dengan jumlah dehidrator $\mathrm{P}_{2} \mathrm{O}_{5} \%(\mathrm{~b} / \mathrm{b})$ dan lama reaksi 1 jam. (3) Studi pengaruh jumlah dehidrator dilakukan dengan variasi jumlah dehidrator $1,2,3,4,5 \% \mathrm{~b} / \mathrm{b}$ pada suhu $175^{\circ} \mathrm{C}$ dan waktu reaksi 1 jam.

Setiap parameter yang dipelajari dibuat data GC, sedangkan DCO paling optimal dibuat data spektra FTIR dan GC - MS yang dibandingkan terhadap minyak jarak minyak jarak.

\section{HASIL DAN PEMBAHASAN}

Minyak jarak yang digunakan sebagai bahan awal mempunyai kadar risinoleat $86,40 \%$ dan linoleat $7,74 \%$ yang dianalisis dengan GC. Sedangkan komposisi berdasarkan analisis dengan GC-MS adalah : $1,57 \%$ palmitat ; $5,64 \%$ linoleat ; $4,86 \%$ oleat dan $85,26 \%$ risinoleat dengan kromatogram seperti pada Gambar 2 dan spektra FTIR pada Gambar 3.

Perbedaan kadar risinoleat dan linoleat berdasarkan analisis dengan GC dan GC-MS adalah karena perbedaan sensitivitas dan kondisi yang digunakan. Untuk pengkajian faktor waktu, suhu dan jumlah dehidrator, maka yang digunakan sebagai patokan adalah berdasarkan analisis dengan GC, karena reaksi dehidrasi dipandu berdasarkan analisis dengan GC. Gugus fungsional utama yang terlibat pada reaksi dehidrasi adalah $-\mathrm{OH}(3425,58$ $\left.\mathrm{cm}^{-1}\right)$ dan $\mathrm{C}=\mathrm{C}\left(1651,07 \mathrm{~cm}^{-1}\right)$ pada spektra FTIR (Gambar 3).

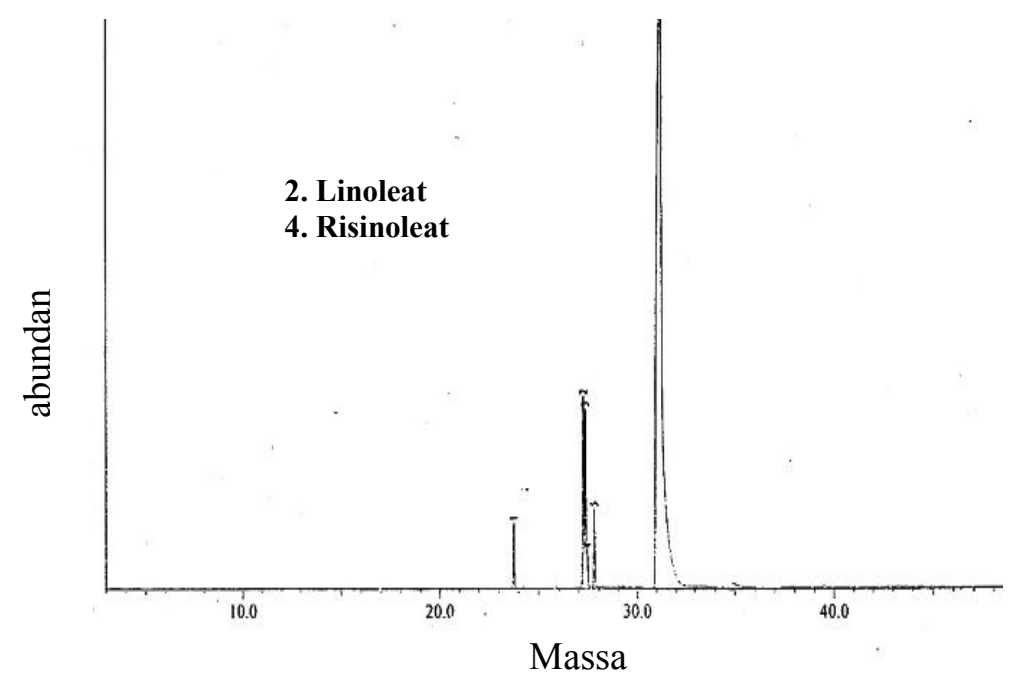

Gambar 2. Kromatogram GC-MS minyak jarak 


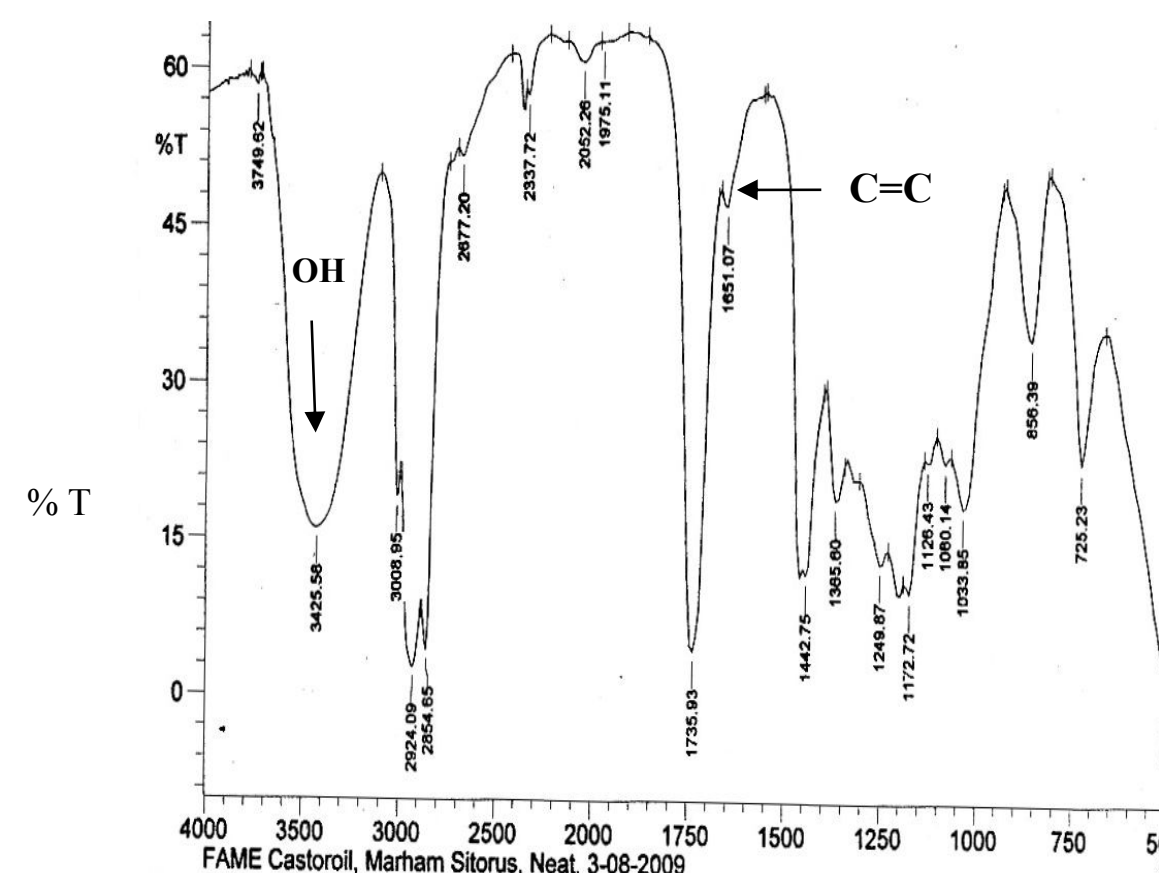

Gambar 3. Spektra FTIR minyak jarak

\section{Studi Pengaruh Waktu Reaksi Pada Dehidrasi Risinoleat}

Pengaruh waktu reaksi diikuti dengan GC berdasarkan penurunan kadar risinoleat dan kenaikan kadar DCO yaitu campuran linoleat (LA) yang masih bergabung dengan CLA (Linoleat/CLA) karena keduanya merupakan isomer yang hanya dibedakan posisi ikatan rangkap dengan hasil seperti Tabel 1 dan Gambar 4.

Tabel 1 dan Gambar 4 menunjukkan bahwa kenaikan waktu akan menaikkan konversi (Yield) hasil dehidrasi. Dehidrasi pada waktu waktu 4 jam dengan konversi reaksi (Yield) sebesar $96,11 \%$ diasumsikan bahwa reaksi telah sempurna sehingga disimpulkan waktu optimal adalah 4 jam. Hal ini juga didukung fakta bahwa tidak ada reaksi senyawa organik yang berlangsung sempurna dan setiap raksi mempunyai harga $\mathrm{K}$ antara 0 dan tidak berhingga. Grafik konsentrasi (C) lawan waktu (t) adalah asimtotis atau akan memotong sumbu t pada tak berhingga, yang berarti reaksi sempurna tidak akan pernah dicapai.

\section{Studi Pengaruh Suhu Pada Dehidrasi Risinoleat}

Hasil analisis perobahan komposisi DCO dengan variasi suhu pada dehidrasi risinoleat terdapat pada Tabel 2 dan Gambar 5.

Berdasarkan Tabel 2 dan Gambar 5 maka secara umum kenaikan suhu menurunkan kadar risinoleat dan menaikkan kadar LA dan CLA. Suhu optimal dehidrasi adalah $200^{\circ} \mathrm{C}$ karena pada suhu tersebut dihasilkan penurunan kadar risinoleat dan kenaikan kadar LA dan CLA paling tinggi. Reaksi pada suhu $225^{\circ} \mathrm{C}$ mengindikasikan terjadi banyak hasil samping dimana berdasarkan data GC kadar risinoleat sisa $7,70 \%$ namun kadar LA dan CLA hanya $2,23 \%$ dimana muncul beberapa puncak baru sesudah linoleat dan CLA, serta sesudah risinoleat yang diperkirakan karena terjadi oksidasi dan dehidrogenasi katalitik.

\section{Studi Pengaruh Jumlah Dehidrator Dehidrasi Risinoleat Minyak Jarak}

Hasil analisis perobahan komposisi DCO dengan variasi jumlah dehidrator pada 
dehidrasi risinoleat seperti Tabel 3. dan Gambar 6.

Berdasarkan Tabel 3 dan Gambar 6 maka jumlah dehidrator yang paling optimal adalah $3 \%$ (b/b) karena menyebabkan penurunan kadar risinoleat paling besar dan kenaikan kadar LA dan CLA paling besar. Reaksi dehidrasi dengan jumlah dehidrator 5\% menyisakan risinoleat 3,48\% namun kadar LA dan CLA hanya $9,53 \%$ dan muncul beberapa puncak baru sesudah linoleat dan CLA serta sesudah Risinoleat yang mengindikasikan terjadi berbagai reaksi samping.

Tabel 1. Perubahan Komposisi DCO Pada Dehidrasi Risinoleat Minyak Jarak dengan $2 \%(b / b) \mathrm{P}_{2} \mathrm{O}_{5}$ dan Suhu $175^{\circ} \mathrm{C}$ Variasi Waktu

\begin{tabular}{|c|c|c|}
\hline Waktu (jam) & $\begin{array}{c}\text { Kadar Risinoleat }{ }^{\text {a) }} \\
(\%)\end{array}$ & $\begin{array}{l}\text { Kadar Linolet dan } \\
\text { isomer } \operatorname{CLA}^{\text {a) }}(\%)\end{array}$ \\
\hline $\begin{array}{c}\text { Minyak jarak } \\
\text { (kontrol) }\end{array}$ & 86,40 & 4,74 \\
\hline 1 & 61,67 & 12,78 \\
\hline 2 & 31,77 & 34,62 \\
\hline 3 & 17,48 & 44,24 \\
\hline 4 & 3,36 & 53,56 \\
\hline
\end{tabular}

Keterangan : a) Relatif terhadap luas pucak

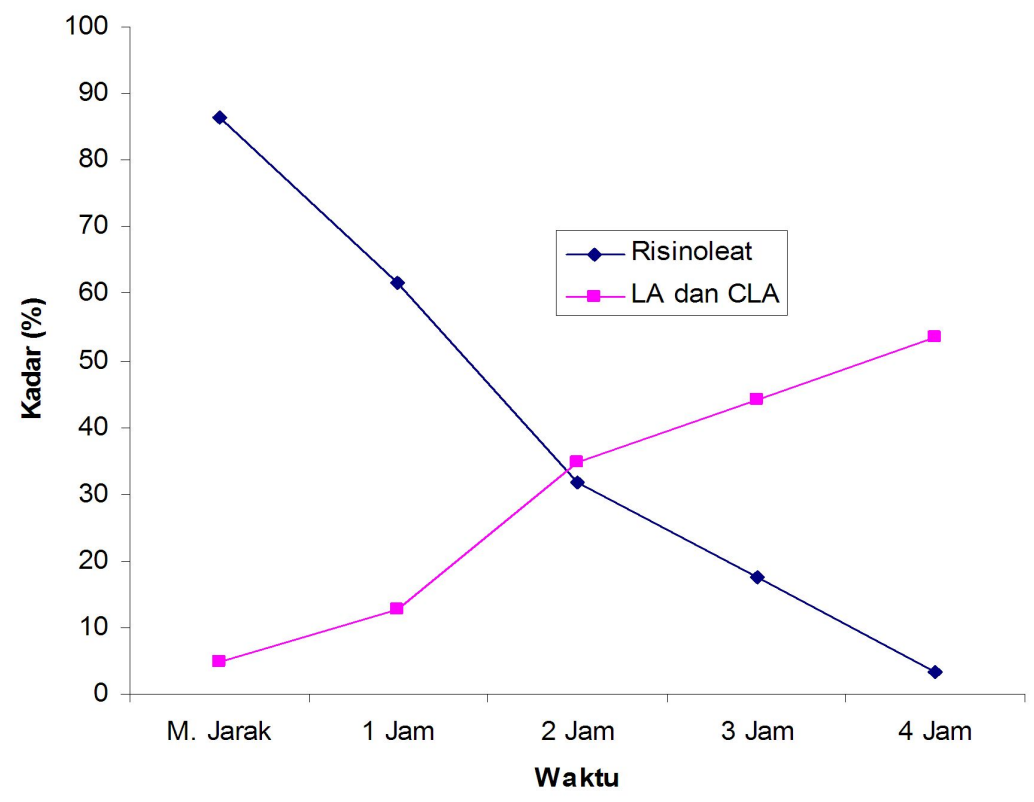

Gambar 4. Perubahan komposisi DCO pada dehidrasi risinoleat minyak jarak dengan $2 \%(b / b) \mathrm{P}_{2} \mathrm{O}_{5}$ dan suhu $175^{\circ} \mathrm{C}$ variasi waktu 
Tabel 2. Perubahan Komposisi DCO Pada Dehidrasi Risinoleat Minyak Jarak dengan $2 \%(b / b) \mathrm{P}_{2} \mathrm{O}_{5}$ dan Waktu 1 Jam Variasi Suhu

\begin{tabular}{ccc}
\hline $\begin{array}{c}\text { Suhu reaksi } \\
\left({ }^{\circ} \mathbf{C}\right)\end{array}$ & $\begin{array}{c}\text { Risinoleat } \\
\mathbf{( \% )}\end{array}$ & $\begin{array}{c}\text { Kadar } \\
\text { Linoleat/CLA } \\
(\%)\end{array}$ \\
\hline Minyak.jarak (kontrol) & 86,40 & 4,74 \\
100 & 84,34 & 5,79 \\
125 & 77,25 & 8,68 \\
150 & 77,19 & 9,11 \\
175 & 64,47 & 16,23 \\
200 & 34,77 & 30,15 \\
225 & 7,70 & 2,23 \\
\hline
\end{tabular}

Keterangan : a) Relatif terhadap luas puncak

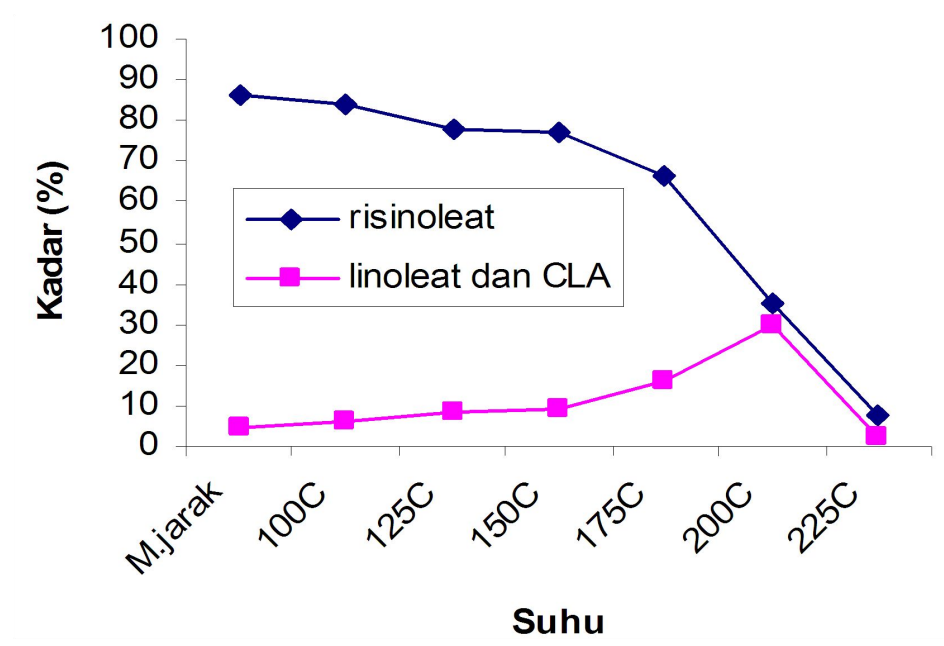

Gambar 5. Perubahan Komposisi DCO Pada Dehidrasi Risinoleat Minyak Jarak dengan 2\% (b/b) $\mathrm{P}_{2} \mathrm{O}_{5}$ dan Waktu 1 Jam variasi suhu

Tabel 3. Perubahan Komposisi DCO pada Dehidrasi Risinoleat Minyak Jarak pada Suhu $175^{\circ} \mathrm{C}$ dan Waktu 1 Jam Variasi Jumlah Dehidrator

\begin{tabular}{ccc}
\hline $\begin{array}{c}\text { Jumlah Dehidrator } \mathbf{P}_{\mathbf{2}} \mathbf{O}_{\mathbf{5}} \\
(\mathbf{\%} \mathbf{b} / \mathbf{b})\end{array}$ & $\begin{array}{c}\text { Risinoleat } \\
\mathbf{( \% )}\end{array}$ & $\begin{array}{c}\text { Linoleat/CLA } \\
\mathbf{( \% )}\end{array}$ \\
\hline Minyak jarak (kontrol) & 86,40 & 4,74 \\
1 & 77,34 & 8,97 \\
2 & 66,47 & 16,13 \\
3 & 46,18 & 24,19 \\
4 & 47,31 & 21,97 \\
5 & 3,48 & 9,53 \\
\hline
\end{tabular}

Keterangan : a) Relatif terhadap luas puncak 


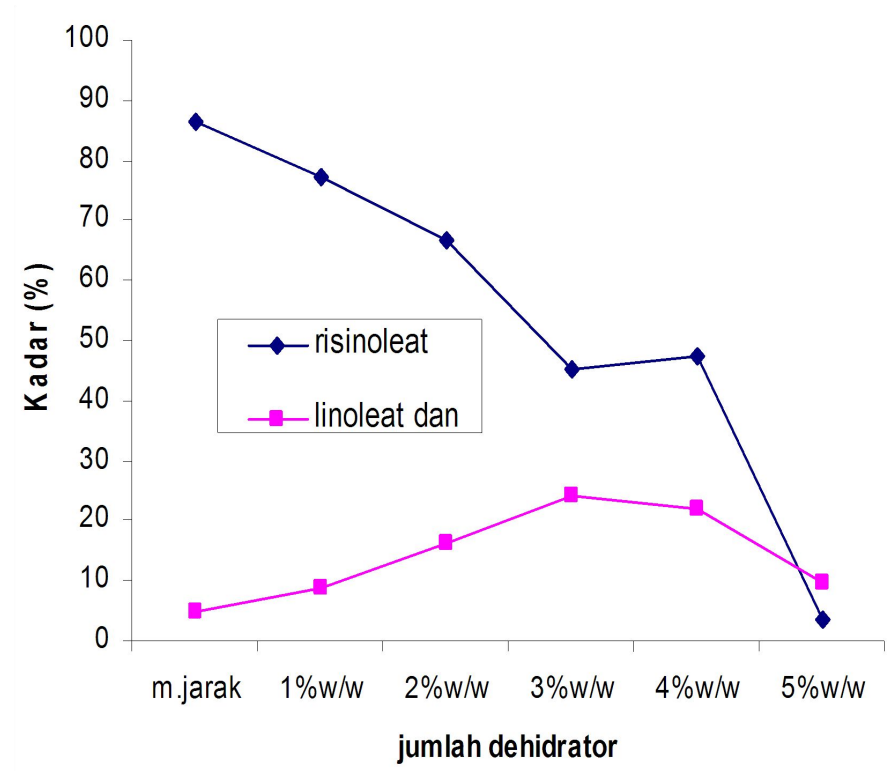

Gambar 6. Perubahan komposisi DCO pada dehidrasi risinoleat minyak jarak pada suhu $175^{\circ} \mathrm{C}$ dan waktu 1 jam variasi jumlah dehidrator

\section{Dehidrasi Risinoleat Pada Kondisi Optimal}

Berdasarkan hasil optimasi waktu, suhu dan jumlah dehidrator $\mathrm{P}_{2} \mathrm{O}_{5}$ pada dehidrasi risinoleat minyak jarak maka diperoleh kondisi dehidrasi optimal adalah : $4 \mathrm{jam}, 200^{\circ} \mathrm{C}$, dan $3 \%(\mathrm{~b} / \mathrm{b}) \mathrm{P}_{2} \mathrm{O}_{5}$. Dehidrasi pada kondisi optimal tersebut dicobakan pada percobaan ini dengan kromatogram GC - MS pada gambar 7.

Berdasarkan hasil interpretasi terhadap MS tiap puncak maka komposisi standar CLA adalah: $1,23 \%$ linoleat $(9 \mathrm{c}-12 \mathrm{c}) ; 31,55$ linoleat $(9 \mathrm{c} / \mathrm{t}-12 \mathrm{t} / \mathrm{c}) ; 42,80 \%$ CLA $(9 \mathrm{c} / \mathrm{t}-$ $11 \mathrm{t} / \mathrm{c}) ; 8,04 \%$ linoleat $(9 \mathrm{t}-12 \mathrm{t})$; dan $16,38 \%$ $(9 \mathrm{t}-11 \mathrm{t})$. Standar CLA masih merupakan campuran dengan linoleat, karena keduanya adalah merupakan isomer yang berbeda posisi ikatan rangkap sehingga sifat fisika dan kimianya berdekatan (mirip). Total perbandingan CLA : linoleat adalah 1,45: 1 . Komposisi minyak jarak hasil dehidrasi (DCO) pada kondisi optimal adalah: 1,02\% linoleat $(9 \mathrm{c}-12 \mathrm{c}) ; 41,97 \%$ linoleat $(9 \mathrm{c} / \mathrm{t}-12 \mathrm{t} / \mathrm{c})$; $19,50 \%$ CLA $(9 \mathrm{c} / \mathrm{t}-11 \mathrm{t} / \mathrm{c}) ; 19,79 \%$ CLA $(9 \mathrm{t}-$ 11t); dan sisa risinoleat $0,90 \%$. Konversi (Yield) reaksi berdasarkan laju pengurangan risinoleat adalah 98,98\%. Konversi ini sangat tinggi dan diasumsikan bahwa reaksi dehidrasi telah berjalan sempurna. Perbandingan total CLA : linoleat yang dihasilkan adalah 0,92: 1 , dengan pencapaian sebesar $63,45 \%$ dibanding standar otentik .

Spektra FTIR DCO dehidrasi pada kondisi optimal (4 jam, $200^{\circ} \mathrm{C}$ dan $3 \%(\mathrm{~b} / \mathrm{b}) \mathrm{P}_{2} \mathrm{O}_{5}$ ) dan standar otentik CLA adalah pada Gambar 8.

Bila serapan gugus $-\mathrm{OH}$ pada DCO dehidrasi pada kondisi optimal $\left(3458,88 \quad \mathrm{~cm}^{-1}\right)$ dibandingkan dengan serapan $-\mathrm{OH}$ pada spektra FTIR minyak jarak $\left(3448,72 \mathrm{~cm}^{-1}\right)$ Gambar 3, terjadi penurunan intensitas sebesar $92,83 \%$ mengindikasikan terjadinya dehidrasi risinoleat. Hal ini juga didukung keidentikan pola spektra FTIR antara DCO pada dehidrasi pada kondisi optimal dan CLA standar (Gambar 8), khususnya serapan $\mathrm{C}=\mathrm{C}$ konjugasi . 


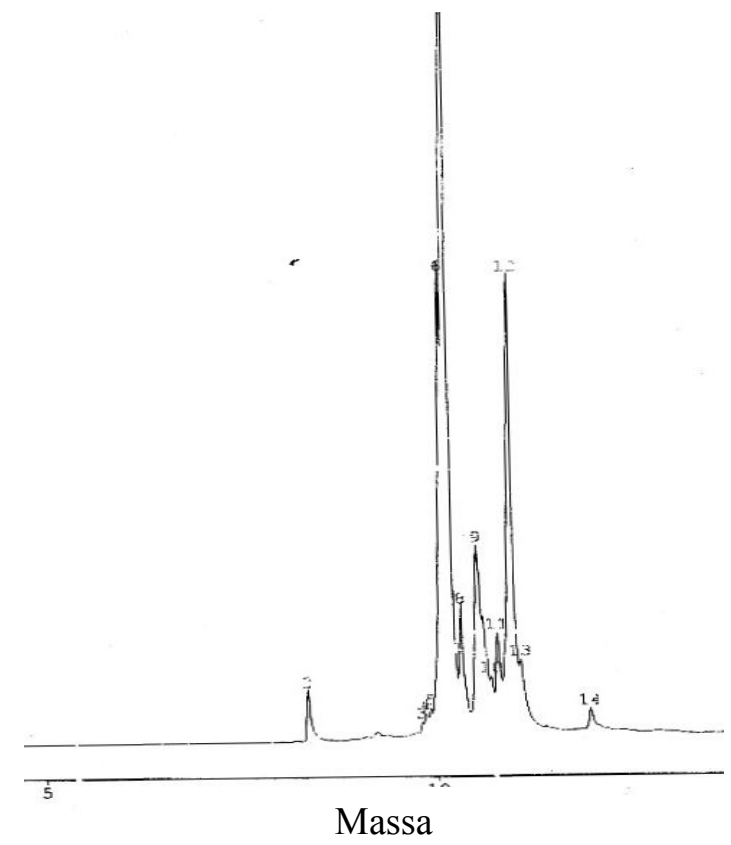

a

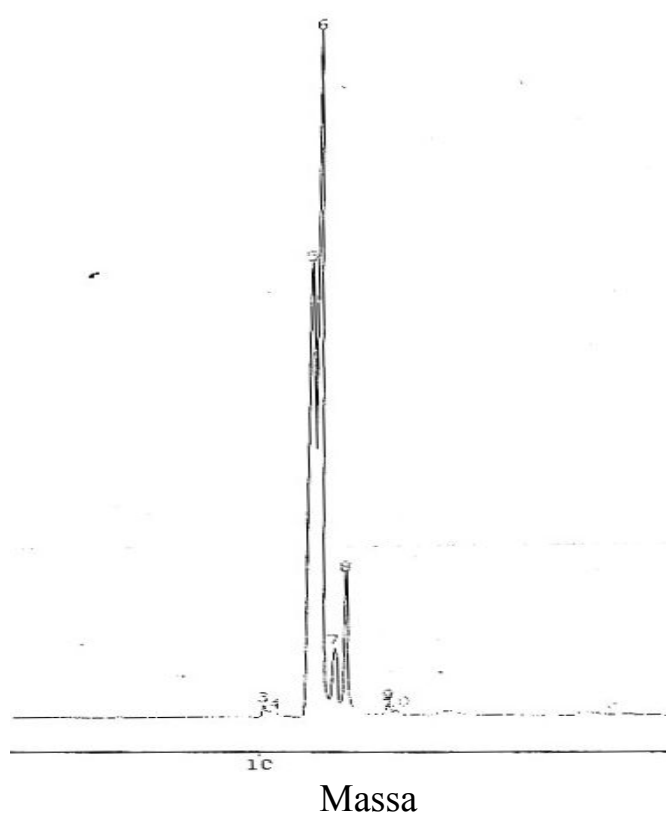

$\mathbf{b}$

Gambar 7. Kromatogram GC - MS DCO dehidrasi pada kondisi optimal (4 jam, $200^{\circ} \mathrm{C}$ dan $3 \%$ (b/b) $\mathrm{P}_{2} \mathrm{O}_{5}$ (a), dan standar CLA (b)

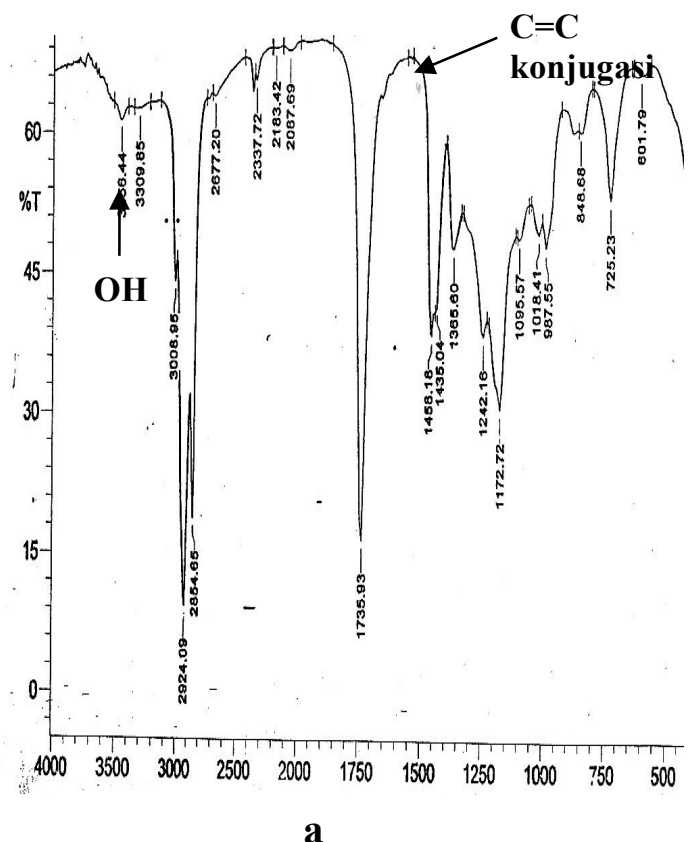

$\mathbf{a}$

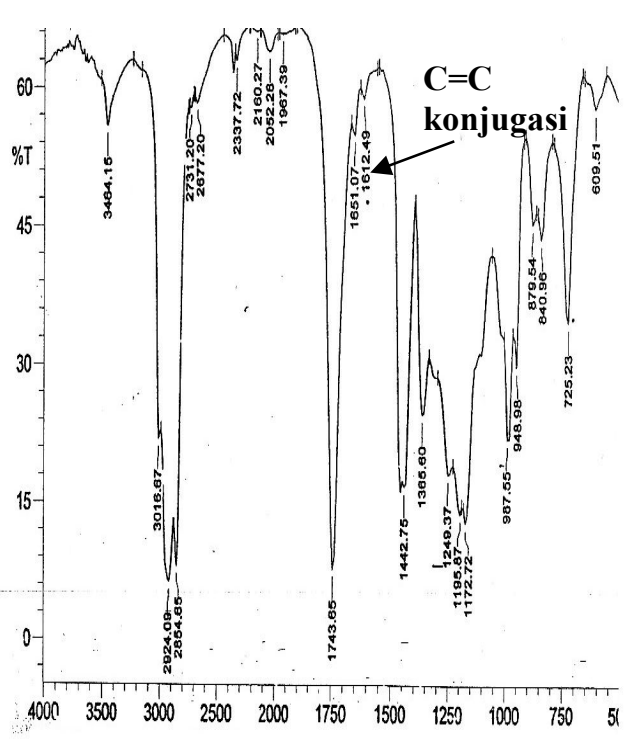

$\mathbf{b}$

Gambar 8. Spektra FTIR DCO dehidrasi pada kondisi optimal (4 jam, $200^{\circ} \mathrm{C}$ dan $3 \%$ (b/b) $\mathrm{P}_{2} \mathrm{O}_{5}$ (a) dan standar CLA (b) 


\section{KESIMPULAN}

Berdasarkan hasil penelitian maka dehidrasi risinoeat minyak jarak dengan dehidrator difosforpentaoksida $\left(\mathrm{P}_{2} \mathrm{O}_{5}\right)$ optimal bila dilangsungkan dengan waktu 4 jam, pada suhu $200^{\circ} \mathrm{C}$, dan jumlah dehidrator $3 \%$ (b/b) dibanding minyak jarak dan waktu reaksi sekitar 1 Jam. Reaksi dilakukan pada aliran gas nitrogen, pengurangan tekanan $50-70 \mathrm{mmHg}$ dan kecepatan pengadukan $800-1000 \mathrm{rpm}$ dan penambahan sekitar 0,1 g serbuk $\mathrm{Zn}$ sebagai agen anti polimerisasi. Pada kondisi ini konversi (yield) adalah 98,98\% dengan komposisi 1,02\% linoleat (9c-12c); 41,97\% linoleat $(9 \mathrm{c} / \mathrm{t}-12 \mathrm{t} / \mathrm{c}) ; 19,50 \%$ CLA $(9 \mathrm{c} / \mathrm{t}-$ $11 \mathrm{t} / \mathrm{c}) ; 19,79 \%$ CLA $(9 \mathrm{t}-11 \mathrm{t}) ;$ dan sisa risinoleat $0,90 \%$. Perbandingan total CLA : linoleat yang dihasilkan adalah $0,92: 1$, dengan pencapaian sebesar $63,45 \%$ dibanding standar otentik dengan perbandingan $1,45: 1$. Hal ini juga didukung data spektra FTIR yang dibandingkan antara minyak jarak dan DCO dehidrasi paling optimal yaitu terjadi penurunan intensitas serapan $(-\mathrm{OH})$ sebesar $92,83 \%$ yang mengindikasikan terjadinya reaksi dehidrasi risinoleat. Terbentuknya gugus alkena konjugasi (CLA) atau tambahan ikatan rangkap ditunjukkan munculnya serapan ganda untuk gugus alkena pada spektra FTIR DCO dehidrasi pada kondisi optimal.

\section{UCAPAN TERIMA KASIH}

Penulis menyampaikan terima kasih kepada $\mathrm{DP}_{2} \mathrm{M}$ Direktorat Jenderal Pendidikan Tinggi (DIKTI) Departemen Pendidikan Nasional yang mendanai Penelitian ini melalui proyek Penelitian Hibah Bersaing (HB) untuk Tahun Anggaran 2009/2010. Terima kasih juga disampaikan kepada Marida, Purnama, J. Purba, M. Sinaga dan M. Nizam atas kontribusinya pada penelitian untuk bahan tulisan ini.

\section{DAFTAR PUSTAKA}

1. W.G. Priest and J. D. Von Mikusch, Composition and Analysis of Dehydrated Castor Oil, Woburn Degreasing Company of New Jessey, New York, 1997.
2. M. Sitorus, Dehidrasi Isoamil Alkohol Hasil Samping Pabrik Gula Menjadi Alkena (Tidak dipublikasi), Kimia FMIPA UGM, Yoyakarta, 1987.

3. M. Laniwati, Kajian Awal Dehidrasi N Butanol Menjadi Senyawa Buten Dengan Katalis Analsim, Prosiding Seminar Nasional Fundamental Dan Aplikasi Teknik Kimia, Surabaya, 24 - 25 Nopember, 1999.

4. M. Nasikin, Dealuminasi Untuk Meningkatkan Stabilitas Thermal Zeolit Alam Sebagai Katalis Pada Reaksi Dehidrasi Etanol Menjadi Etilen, Prosiding Seminar Nasional Fundamental Dan Aplikasi Teknik Kimia, Surabaya, 24 - 25 Nopember, 1999.

5. M. Nurhayati, Laniwati dan Subagjo, Kinetika Dehidrasi N-Butanol Pada Katalis Alumina Aktif, Prosiding Seminar Nasional Fundamental Dan Aplikasi Teknik Kimia, Surabaya, 24 - 25 Nopember, 1999.

6. I. Rusman, I. Fallah, dan R. H. A. Shahirul Alim, The Intecalation Copper Into Active Carbon And Its Applications As a Cathalyst for $\mathrm{n}$ - amylalchohol Dehydration, Indonesian J. of Chemistry, 4: 23 - 29, (2000).

7. M. Nurhayati dan Subagjo, Analisis Thermodinamika Dehidrasi n - Butanol, Prosiding Seminar Nasional Fundamental Dan Aplikasi Teknik Kimia, Surabaya, 24 - 25 Nopember, 1999.

8. K, Ginting, M. Ginting, dan H. Sihotang, Dehidrasi Risinoleat Yang Terdapat Dalam Minyak Jarak (Ricinus Comunis L) Menggunakan Molekuler Sieve Secara Refluks Dalam beberapa Pelarut Organik (Tidak dipublikasi), Lembaga Penelitian Lemlit USU, Medan, 2003.

9. T. I. Handayani dan D. Ariono, Pembuatan Drying Oil Dari Minyak Jarak, (Tidak dipublikasi), Laporan Penelitian Lemlit ITB Bandung, 2005.

10. K. Setyowati, Formulasi Campuran Natrium Bisulfat Sebagai Katalis Dehidrasi Minyak Jarak, Paten No : P00200400341, 2002.

11. K. Setyowati, P. Suryagama, dan S. Pusparini, Peningkatan Indeks Viskositas Minyak Jarak Sebagai Bahan Dasar Minyak Pelumas Melalui Proses 
Dehidrasi Dengan Katalis Natrium Bisulfat, Paten No: P00200400341, 2004.

12. M. Sitorus, dan J. Purba, Dehidrasi Risinoleat Minyak jarak (Castor Oil) dan Karakterisasinya Sebagai Usaha Pengolahan Minyak Jarak Untuk Konsumsi (Tidak dipublikasi), Laporan Penelitian PDM Lemlit UNIMED, Medan, 2006.

13. P. Villeneuve, R. Lago, N. Barouh, and B. Barea, Production of Conjugated Linoleic Acid Isomers by Dehydration and Isomerization of Castor Bean Oil, JAOCS, 82: $261-270,(2005)$
14. D. N. Bhowimick, and A. N. Sarma, Dehydration of Castor Oil, Ind. Eng. Chem. Prod, Departement of Oil and Paint Technology Kampur India, 1987.

15. W. W. Cristie, Gas Chromatography Mass Spectrometry Methods for Structural Analysis of Fatty Acid, Lipids, 33: 343 - 353, (1998).

16. W. W. Cristie, G. Dopson, and R. O. Adlof, A Practical Guide to The Isolation, Analysis and Identification of Conjugated Linoleic Acid; Lipids, 42: 1073 - 1025, (2007). 